\title{
In the Name of Socialism: Zionism and European Social Democracy in the Inter-War Years
}

\author{
PAUL KELEMEN*
}

Summary: Since 1917, the European social democratic movement has given fulsome support to Zionism. The article examines the ideological basis on which Zionism and, in particular, Labour Zionism gained, from 1917, the backing of social democratic parties and prominent socialists. It argues that Labour Zionism's appeal to socialists derived from the notion of "positive colonialism". In the 1930s, as the number of Jewish refugees from Nazi persecution increased considerably, social democratic pro-Zionism also came to be sustained by the fear that the resettlement of Jews in Europe would strengthen anti-Semitism and the extreme right.

The social democratic movement was an important source of political support for the setting up of a Jewish state in Palestine. Yet its attitude to Zionism has been noted mostly en passant in works tracing the socialist, and in particular the Marxist, interpretations of the Jewish question. ${ }^{1}$ The lack of attention accorded to this issue stems partly from the pre-1914 socialist theoreticians themselves, most of whom considered Zionism, simultaneously, as a diversion from the class struggle and a peripheral issue. In the inter-war years, however, prominent socialists, individual social democratic parties and their collective organizations established a tradition of pro-Zionism. The aim, here, is to trace the ideas and political factors which shaped this tradition.

Before World War I, sympathy for Zionism in the socialist movement was confined to its fringe: articles favourable to Jewish nationalism appeared, from 1908, in Sozialistische Monatshefte, a journal edited by Joseph Bloch and influential on the revisionist right wing of the German Social Democratic Party. ${ }^{2}$ Bloch's belief that the sense of national community transcended class interest as a historical force, accorded with interpreting the Jewish question in national rather than class terms. On

* In carrying out the research for this essay I benefited greatly from discussions with Ahmad Sa'di and Zuhair Sabbagh.

' J. Jacobs, On Socialists and "the Jewish Question" after Marx (New York, 1992); E. Silbemer, Sozialisten zur Judenfrage (Berlin, 1962); E. Traverso, The Marrists and the Jewish Question (New Jersey, 1990); R. Wistrich, Socialism and the Jews (London, 1982).

2 Ibid., p. 150; R. Fletcher, Revisionism and Empire (London, 1984), pp. 57-59.

International Review of Social History 41 (1996), pp. 331-350 
the whole, however, Zionism attracted little attention outside Jewish communities until the spring of 1917, when the British invasion of Palestine raised the prospect of the Ottoman Empire's final demise. A specially convened conference of the British Labour Party and TUC, in August 1917, to ratify the National Executive's proposals for ending the war, called for Palestine to be set free "from the harsh and oppressive government of the Turk, in order that this country may form a Free State under international guarantee, to which such of the Jewish people as desire to do so may return [...]".3 In October 1917, the DutchScandinavian Committee, which had been formed at the instigation of the socialist parties of the neutral countries, also published a peace manifesto. On the Jewish question, as well as calling for "personal autonomy", in the countries where Jews lived as large minorities, it stated that the "promotion of Jewish colonization in Palestine will have to be legally and internationally safeguarded".+ The committee's secretary, the Belgian socialist, Huysmans, explained that the catastrophe of the world war had demonstrated that individual states could not be trusted with the fate of national minorities." The conference of the socialist parties of the allied countries, which met in London in early 1918 , approved with minor changes the British labour movement's peace proposals and retained the clause supportive of Jewish settlement in Palestine.

Reflecting this favourable attitude to Zionism, Poale Zion, the main Labour Zionist party in Palestine, gained acceptance by the international socialist movement. The Palestine party belonged to a federation of Poale Zion parties from various countries, which was affiliated to the World Zionist Organization. The federation was invited to join in the founding of the Vienna-based "two and a half" International, which hoped to bring under the same umbrella revolutionary and reformist parties. In 1924, after the remnant of the Second International and the Vienna International had amalgamated to form the LSI (Labour and Socialist International), the Palestine Poale Zion affiliated. Jarblum, who became its representative on the LSI Executive, described the party's incorporation as a significant achievement: "sympathy for the work of Jewish labour in Palestine grew from day to day within the frame of the Socialist International, thanks to the unremitting propaganda of the Poale Zion, and owing to the enthusiasm of many of the leading Socialist figures who had seen the Chalutzim, or pioneer workers, in the flesh".6 Jarblum's

${ }^{3}$ Labour party and Trades Union Congress, Memorandum on War Aims (London, 1917); the Inter-Allied Labour and Socialist Conference's version is contained in C. McCurdy, A Clean Peace (London, 1918).

4uoted in M. Jarblum, The Socialist International and Zionism (New York, 1933), p. 17.

3 Sonderbeilage zu No. 52 der "Mlitteilungen des Kopenhagener Bureaus der zionistischen Organisation". A137/76, Central Zionist Archives (Jerusalem).

- Jarblum. The Socialist International and Zionism, p. 17. 
feeling, that an important door had opened for Zionism, was enhanced by the fact that the Second International's pre-war record on the Jewish question had not presaged a positive attitude to Zionism. At the 1891 International Socialist Congress, a specific condemnation of anti-Semitism had been opposed by some representatives on the grounds that it was superfluous since, for socialists, workers of all nationality were brothers. It was an argument motivated, at least in part, by the fear privately expressed to Cahan by the Austrian socialists, Victor Adler and Paul Singer, both of Jewish origin, that it would hand anti-Semites the propaganda weapon of portraying socialists as the defenders of Jews.? The Congress's final resolution, condemning both anti-Semitism and philo-Semitism, resonated with ideas that, as Wistrich shows, had found disciples among Austrian and German socialists. They held that antiSemitism had an anti-capitalist thrust - a phase in the evolution towards class consciousness - and claimed that the defence of Jews, qua Jews, served as a pretext for liberals to defend the capitalist class. ${ }^{8}$

The failure of the Second International to recognize the reactionary character of anti-Semitism undoubtedly also encouraged a dismissive attitude towards Zionism. As Jarblum recalls, Poale Zion's applications for acceptance to the Second International were unsuccessful in 1907, 1908 and $1911 .{ }^{9}$ The fundamental obstacle to the pre-war socialist movement embracing either Zionism or the Bund was its opposition to the idea that Jews should organize on a national basis. Lenin, Luxemburg, Kautsky and Otto Bauer, despite their divergences on the national question, all agreed that it was not desirable for Jews to develop either a sovereign or an autonomous national existence. By the end of the war, the socialist movement that emerged from the split with the Communists acknowledged the right of ethnic groups to a separate identity and to self-determination. Commenting on the first peacetime conference of socialists that in January 1919 brought together, in Berne, ninety-seven delegates from over twenty countries, Ramsay MacDonald wrote triumphantly: "Nationality has been accepted by the Marxist Socialists as a dominating factor in making war and as the basis of states. That is a new emphasis. Economics and material things are not the only things in life." And at the same gathering, Huysmans won approval for his proposal that nationalities be given the same rights as states and governments in the League of Nations."

The socialist movement's endorsement of the principle of national self-determination for Jews was to be confronted, however, by a rival

' Silberner, Sozialisten zur Judenfrage, p. 280.

- Wistrich, Socialism and the Jew's, pp. 242-261.

9 Jarblum, The Socialist International and Zionism, p. 9.

10 Fonward, 1 March 1919.

"A. Van der Slice, International Labour, Diplomacy and Peace 1914-1919 (Philadelphia, 1941), p. 318. 
claim: the Palestinian Arabs' right to self-determination. The first serious outbreaks of Palestinian Arab hostility against Jews, in 1920 and 1921, forced both pro- and anti-Zionist socialists to recast their case. It provoked from the Communist movement, but also from Kautsky, a line of attack which the socialist supporters of Zionism had to fend off.

Before the war Kautsky had argued against Zionism on the basis that Jews did not constitute a nation. They lacked, he said, a common territory and language as well as sufficient numbers in all the social classes to make up a modern nation. He predicted that the development of capitalism by eroding the special functions that Jews had in feudal society would lead to their assimilation. Zionism was therefore "utopian" and "reactionary" because it did not follow the development of capitalist industrialization, "the line of necessary evolution". ${ }^{12}$ The Labour Zionist riposted that, even in the West, the pre-capitalist functions of Jews had not completely ceased, while in Eastern Europe, despite capitalism, "the economic abnormality of Jews" persisted. ${ }^{13}$ Thus the debate had centred on Europe, on tendencies for and against assimilation and on how the Ostjuden should respond to their economic circumstances. After the war, the focus shifted: socialists concentrated on the society Zionism proposed to build in Palestine and the impact of this on the Arab world. This represented a significant change, as not even Zionism's strongest opponents "ever challenged it before 1914 in terms of its possible effects in Palestine". ${ }^{14}$ Kautsky reflected this development. In the wake of the 1921 riots, he extended his critique of Zionism to give weight to the Arab anti-colonial struggle. The "most deep-seated reason why Zionism could not succeed", he wrote, "was the dependence of Jewish colonization on the victorious great European powers and the opposition in the Muslim world to Jewish colonization". And he added: "Like everywhere, the idea of the right of people to dispose of themselves, once it has penetrated into the broad masses is also irresistible in the Near East: that is the actual situation". ${ }^{15}$

In response to the 1929 Arab-Jewish clashes in Palestine, Kautsky quoted his 1921 assessment in an article in Vorwärts, to highlight the extent to which events had borne out his analysis. ${ }^{16}$ The article was widely commented on and could not be ignored by socialist supporters of Zionism. The Belgian socialist leader, Vandervelde, feared that the intervention of one of the social democratic movement's revered figures "could not fail to make an impression on those who have no fixed opinion on this subject". ${ }^{17}$

12 K. Kautsky, Are the Jews A Race? (London, 1926), p. 207; J. Jacobs, "Marxism and Anti-Semitism: Kautsky's Perspective", Intemational Review of Social History, 30, 3 (December 1985), p. 426.

13 B. Locker, "Karl Kautsky und der Zionismus", Der Neue Weg, December 1924.

it Wistrich, Socialism and the Jews, p. 167.

is Quoted in Vonvirts, 29 September 1929.

16 Ibid.

17 La Vie Socialiste, December 1929. 
Yet, notwithstanding Kautsky's prestige and his argument being periodically reiterated in the pages of Die Neue Zeit, of which until 1917 he had been the editor, there emerged barely any opposition to Zionism from the European socialist movement. Kautsky's influence had declined after the war as the German Social Democratic Party went into disarray and no longer provided ideological leadership to the international socialist movement. Otto Bauer, though also opposed to Zionism, was equally ineffective. The renowned Austro-Marxist theoretician on the national question did not publicly intervene on this issue after 1918, but, in any case, his influence, too, had waned: "war and revolution", as Bauer himself noted, "dissolved the Austro-Marxist school". ${ }^{18}$ His observation holds with respect to Zionism: while Bauer remained hostile to it, Max Adler wrote in its support. The LSI Executive was divided on Zionism, too, and refrained from expressing a position. A resolution proposed at its meeting, in May 1930, by two opponents of Zionism asked for Poale Zion branches to join the class struggle in the countries they operated in, and not to subordinate everything to their interest in Palestine. ${ }^{19}$ The resolution was abandoned without a decision, but still more significant is that its promoters did not challenge the central objectives of Zionism.

The Bund's opposition was more fundamental, but did not carry much influence either. It wanted Jewish workers to struggle for socialism wherever they lived, but through their separate, national organizations, and accused Zionists of seeking to lead Jewish workers into a struggle that, even if successful, could provide a solution only to a small fraction of European Jewry. The Bund's arguments may have made a greater impact on the social democratic parties had it had closer relations with the latter, but until 1930 the Bund distanced itself from the LSI, considering it too reformist, though it also had basic differences with the Communists. Furthermore, the Bund's political strength lay among Jewish workers in Poland and in the US, but it was weak in Western Europe, where socialist backing for Zionism was mainly concentrated. In the rivalry with Poale Zion for international support, the Bund was, consequently, at a disadvantage.

Poale Zion had a much smaller membership than the Bund but, by the 1920s, it had established close contacts with the international labour movement. ${ }^{20}$ MacDonald, Vandervelde, Morrison and Braunthal, for

"Otto Bauer, "What is Austro-Marxism?", in T. Bottomore (ed.), Austro-Marxism (Oxford, 1979), p. 46.

19. Glasneck, "Die Intemationale Sozialdemokratie und die Zionistische PalästinaKolonisation in den Jahren 1929/30", Wissenschaftliche Zeitschrift der Martin Luther Universität, G-H., 26, 4 (1977), p. 48.

${ }^{20}$ Poale Zion reported to the Socialist International, in 1925, a membership of 13.500 of which 3,350 were in Palestine, 3,000 in the US and the rest spread over a half dozen countries. In 1934, its membership outside Palestine was 39,000 spread over a dozen countries. In Belgium and Britain, from where some of the strongest socialist support carne, it had between $500-600$ members for most of the inter-war period. Archivs der 
example, were hosted by the Labour Zionist movement when they visited Palestine and, subsequently, addressed meetings and wrote in its support. In 1928, the Socialist Committee for Workers' Palestine was formed on the initiative of Poale Zion, to mobilize labour organizations in favour of Zionism. It counted among its founding members several of the most prominent figures of European socialism, including Bernstein, Léon Blum, de Brouckère, Henderson, Huysmans, Lansbury, Löbe, Longuet, Renaudel, Turati and Vandervelde, who became the Committee's president. ${ }^{21}$ The Committee's formation was a clear indication of the strong support that the Zionist organizations, and in particular Poale Zion, had succeeded in establishing among socialist leaders.

The principal reason for Poale Zion's success lay, however, not in its well-organized lobbying and propaganda work but in social democracy's receptiveness to the Labour Zionist viewpoint. Zionism's immediate after-war appeal was on the basis of self-determination, but within a few years the social democratic movement came to see it as the carrier of other projects. Indeed, the principle of self-determination could not, by itself, have secured Zionism the level of socialist support that it was to obtain. The Zionist claim to self-determination had to have additional attributes, to persuade social democrats of its superiority over the Arab claim to Palestine. One significant point of appeal was the socialism advocated by Labour Zionism. MacDonald and Wedgwood praised it for the absence of class struggle and Max Adler and Löbe for it being established without violence. ${ }^{2}$ Vandervelde, like MacDonald before him, was enthusiastic about Labour Zionism's plan to extend Jewish labour's control over the economy - through the unions and cooperatives - as an integral part of nation building. It was, in essential respects, the antithesis of the Bolshevik model: it rejected the dictatorship of the proletariat and envisaged a reconciliation between nationalism and socialism.

A still more important source of Labour Zionism's appeal to social democracy than as an example to use in the struggle against the Communists, came from it being perceived as a form of benign colonialism. The political line on the colonial question that had been advocated by the right wing of the Second International at its Stuttgart Congress in 1907 , and had been rejected at the time, returned to triumph in the socialist position on Zionism.

Sozialistischen Arbeiter Intemationale (hereafter SAI), 2511/28, 134/22 and 3153, Institute of Social History, Amsterdam (hereafter ISH).

2t Comité Socialiste pour la Palestine Ouvrière (hereafter Comite Socialiste), Bulletin no. 1, November 1929.

z J.R. MacDonald, A Socialist in Palestine (London, 1922), p. 23; J. Wedgwood, The Seventh Dominion (London, 1928), p. 114; Adler, quoted in Braunthal to Erlich, December 1935, Braunthal Papers, Letters, no. 48 (ISH); Löbe, quoted in Glasneck, "Die Internationale Sozialdemokratic und die Zionistische Palästina-Kolonisation in den Jahren 1929/30", p. -42 . 
At Stuttgart, van Kol, the Dutch representative, was charged with presenting the majority view of the Colonial Commission. Since 1900, he, along with Bernstein, Vandervelde and Jaurès, had been the principal advocate of a "positive colonial policy". He proposed that the Congress should not condemn "in principle and for all times all colonial policies which under a socialist regime could serve a civilizing purpose". ${ }^{23}$ On the floor of the Congress, Kautsky led the rejection to this proposal and succeeded by 127 votes against 108 to reaffirm the previous condemnation of colonialism. But, notes Haupt, "the majority obtained undoubtedly did not correspond to the attitude of the majority of the delegates: the left owed its 'victory' to the personal prestige of Kautsky"..$^{2+}$ It turned out to be a pyrrhic victory: it was the right wing of the Second International that came to define the post-war socialist attitude to colonialism.

Van Kol and Bloch had argued since before the war that it was the task of socialism to extend its civilization through colonization, both for the benefit of the European working class and for the "backward" peoples. From a slightly different perspective, Bernstein, too, had asserted "the right of people of superior civilization to exercise tutelage over peoples of inferior civilization".2s Ramsay MacDonald and Léon Blum were more equivocal but not fundamentally in disagreement. They were prepared to welcome independence for those nations considered mature enough for it while maintaining that, for the rest, colonialism was appropriate. According to MacDonald, if greater freedom were introduced "to those parts of the world that we possess with lower races populating them it might be possible to carry on a good imperial system along with democracy at home". ${ }^{26}$ Similarly, Blum, defending the French colonial record during the Rif war, declared: "We admit to the right and even to the duty of superior races to pull along with them those that had not reached the same degree of culture and to rouse them to the progress that has been realized by the efforts of science and industry"."7 With the colonial system left intact by the Versailles Peace Agreement, socialist parties were prepared to accede to demands for independence but, as the 1928 Brussels Congress of the LSI made clear, they envisaged continued imperial rule where "the immediate abolition of the colonial states would not bring with it any progress towards a

23 Quoted in M. Reberioux and G. Haupt, "L'attitude de l'Internationale", Le Mouvement Sociale, 45 (October 1963), p. 18 n. 43.

28 Ibid, p. 19.

${ }^{25}$ Sozialistische Monatshefte, vol. 11 (1907), pt. 2, p. 989.

is J.R. MacDonald, "Labour and International Relations", Address delivered on 24 November 1917 at the Annual Conference of the Derby and District ILP Federation (Derby and District ILP Federation, 1917).

${ }^{27}$ Quoted in M. Samidei, "Les Socialistes français et le problème colonial entre les deux guerres, 1919-1939". Rev'ue française du science politigue, 18, 6 (1968), p. 1139. 
national culture, but rather a relapse into primitive barbarism [.. .]". The specific task, in these countries, that the Congress commended to the socialist movement was "the formation and development of a socialist labour movement". ${ }^{28}$ Socialist parties which had participated in government, or anticipated doing so, were only too ready to tone down their immediate post-war enthusiasm for national self-determination and instead emphasize the potential for the more humane administration of the colonies. A contemporary observer noted of the parties at the forefront of the Brussels Congress: "the Labour party of England, and the socialists of France, Holland, and Belgium, are against policies which would seriously disturb the basic relations of their home countries with their colonial dependencies". ${ }^{29}$

Similarly, Labour Zionists intended to promote the development of the "natives" within the existing colonial framework and it was one of the grounds on which they sought common cause with the socialist movement. In 1916 the World Union of Poale Zion, which acted as the umbrella organization for the national parties, published a memorandum by Kaplansky, from its Hague office, addressed to the International Socialist Bureau. The following year Poale Zion made a written submission to the Dutch-Scandinavian Socialist Committee. The two documents marked the beginning of Poale Zion's efforts to gain the backing of the international socialist movement.

Kaplansky's memorandum tried to situate the issue of Jewish colonization in Palestine beyond the dispute that had opposed van Kol and Kautsky at Stuttgart. The distinction that he made between different types of socialist colonial policy implied that, whereas the advocates of a "positive colonial policy" had not envisaged a change in the capitalist economic base of colonialism, Poale Zion was organizing Jewish productive activities according to socialist principles. In contrast to "the monopolist exploitation" in favour of the colonial power, there was, Kaplansky claimed, "a Socialistic colonization policy, which aims at opening up the vast, neglected or still uncultivated regions of the earth for human settlement and civilization [.. ].".30 The Declaration to the DutchScandinavian Committee similarly stressed that Zionist colonization could not be considered exploitative. It opened up "thinly populated and for the most part fallow land" and would "only assist the Arab population to overcome their primitive standards of civilization and economics". ${ }^{31}$

Van Kol was among the first prominent socialist leaders to state his support for Zionism and to link the central arguments of Labour Zionism

B Bulletin of the Labour and Socialist International, series 2, no. 3 (September 1928), p. 11.

3 L. Lorwin, Labour and Internationalism (London, 1929), p. 441.

${ }^{30}$ S. Kaplansky, The Jews and the War (Hague, 1916), pp. 32-33.

31 "Declaration to the Hollando-Scandinavian Committee", in B. Borochov, Class Struggle in the Jewish Nation (New Brunswick and London, 1984), p. 210. 
to the notion of a "socialist colonial policy". In a pamphlet, published in 1919, he pointed out that the war had awakened nationalist feelings of which socialists in the past had expressed suspicion. Yet nationalist movements, he claimed, which respected people's rights, deserved support. Zionism, he argued, did not detract from socialism, rather it organized Jewish workers on socialist principles and overcame their "abnormal" state of dispersal and restlessness. He indicated that Zionism was giving realization to the positive form of colonialism that he had advocated: "As carriers of a great and glorious tradition, the Jews could fulfil in Palestine, a new technical and intellectual mission." ${ }^{32}$

It was also from the perspective of Zionism carrying out an imperial mission that, in 1922, Ramsay MacDonald wrote a series of articles on his travels in Palestine. They first appeared in Forward, the Glasgow-based newspaper of the Independent Labour party, and were later republished, as a pamphlet, by Poale Zion. MacDonald's sympathy for Zionism derived both from a belief in the historical connection of Jews to the Holy Land and from the view that "the Arab population do not and cannot use or develop the resources of Palestine". ${ }^{33}$

The social democratic acceptance of Zionism, on the basis of it being a positive form of colonialism, was accompanied by a portrayal of the Jewish settler as the representative of European civilization in the backward Orient. Alluding to the Arabs' hostility to Zionism, MacDonald remarked: "The winds of Europe are blowing in upon them and they cannot stand the cutting blast." ${ }^{34}$ More than a decade later, Braunthal, commenting on the impact of Jewish colonization, wrote in similar terms: "Piece by piece, the Oriental organization of society is breaking up; Europe is pressing in; Europe - but in Palestine that means the Jews". And he added: "The fellaheen is gradually learning to read, write and think. Thus from the cultural front also, Europe is penetrating the Oriental despotism of the effendi." 35 The Jewish pioneer was invariably favourably contrasted with the Arabs. The "Jews have fertilized Palestine, while the Arabs have done nothing, or very little [...]", wrote Huysmans; ${ }^{36}$ while the Fabian, Snell, contrasted the transforming impact of Jewish settlers, with land under Arab cultivation, which "was not being ploughed: it was being tickled and annoyed". ${ }^{37}$

32 H.-H. van Kol, La Democratie Socialiste Intermationale et le Sionisme (Lausanne, 1919), p. 33.

${ }_{33}$ MacDonald, A Socialist in Palestine, p. 19.

34 Ibid, p. 20.

3s J. Braunthal, "Arabs and Jews in Palestine", Contemporary Review, 149 (April 1946), pp. $472-473$.

36 La Vie Socialiste, December 1929.

${ }^{37}$ H. Snell, Man, Movement and Myself (London, 1936), p. 240. Snell's derogatory remark appears to be a reference to the use of the nail plough by Arab peasants. Since he had been a farm labourer in his youth, he presumably felt qualified to make such a judgement but, in 1930, the director of the Jewish Agency's agricultural research institute in Palestine, 
Zionism, for mainstream social democracy, was not merely an outpost of European civilization and economic progress but represented, under the aegis of the Jewish labour movement in Palestine, trade unionism and socialism, the highest achievements of that civilization. Socialism had put down roots only in European civilization, reflected Vandervelde, but a Jewish home in Palestine would "open the way for the penetration of socialism in to Asia which will not be confined to fermenting sterile rebellions [. . . ]" ${ }^{38} \mathrm{He}$ argued that it was the work of Labour Zionists which made Jewish colonization in Palestine a progressive phenomenon. If, as a result, "Palestine became like other colonies", he wrote, "that would be on the whole an insignificant fact. What inspires many with a passionate interest, is that Palestine is not like any other colony but, on the contrary, more than any other, a land of marvellous social experiments, brimming with idealism". ${ }^{39}$ Socialists concerned with Palestine generally sympathized with Poale Zion's aspiration to extend, through colonizations, trade unions, communal agriculture and socialist ideas. From this perspective, Arab hostility to Jewish settlers belonged not to the nationalist awakening in the colonial world but to the ruling elite's resistance to working-class politics. The Jewish worker, MacDonald claimed, "is helping the Arab to raise his standards. It is a stiff job, but in labour disputes the Arab workman has already begun to back the Jew." And he concluded, "economic contacts are bringing the races into harmony. But that harmony seems to the Arab leaders to be an offence." $" * 0$

These lines were written at a time when the Histadrut (the General Federation of Jewish Labour) was already pressing for Jewish enterprises to employ exclusively "Hebrew labour". Only in the public sector, where it had no hope of realizing this, was it prepared for some cooperation with Arab workers." But the Zionist Labour movement's sectarian policy towards Arab workers did not prove to be a barrier in its efforts to gain social democratic support. Kautsky, in his criticisms of Zionism in the 1920s, did not raise it. Josiah Wedgwood, the Labour MP, and Emile Vandervelde reported on the separate organization of Jewish workers, but endorsed the Labour Zionist explanation that this was

who had knowledge of the local conditions and cannot be suspected of undue sympathy for Arab farming methods, gave a significantly different assessment: "When rain comes down for a long time continuously or with brief intervals, the Arab plough is the only one with which work can be done. In such conditions the European plough [with its broad iron share] does not cut the ground, but packs the dust together, makes bricks, rolls the earth into clods, and damages the ground for years. Hence in rainy years the Arab plough prolongs the working season." Quoted in C.S. Kamen, Linle Common Ground (Pittsburgh, 1991), p. 301 n. 15.

${ }^{38}$ Comité Socialiste, Bulletin no. 1, November 1928.

39 E. Vandervelde, Le pays d'Israel (Paris, 1929), p. 211.

4- MacDonald, A Socialist in Palestine, p. 19.

${ }^{4}$ M. Shalev, Labour and the Political Economy in lsrael (New York, 1992), p. 41. 


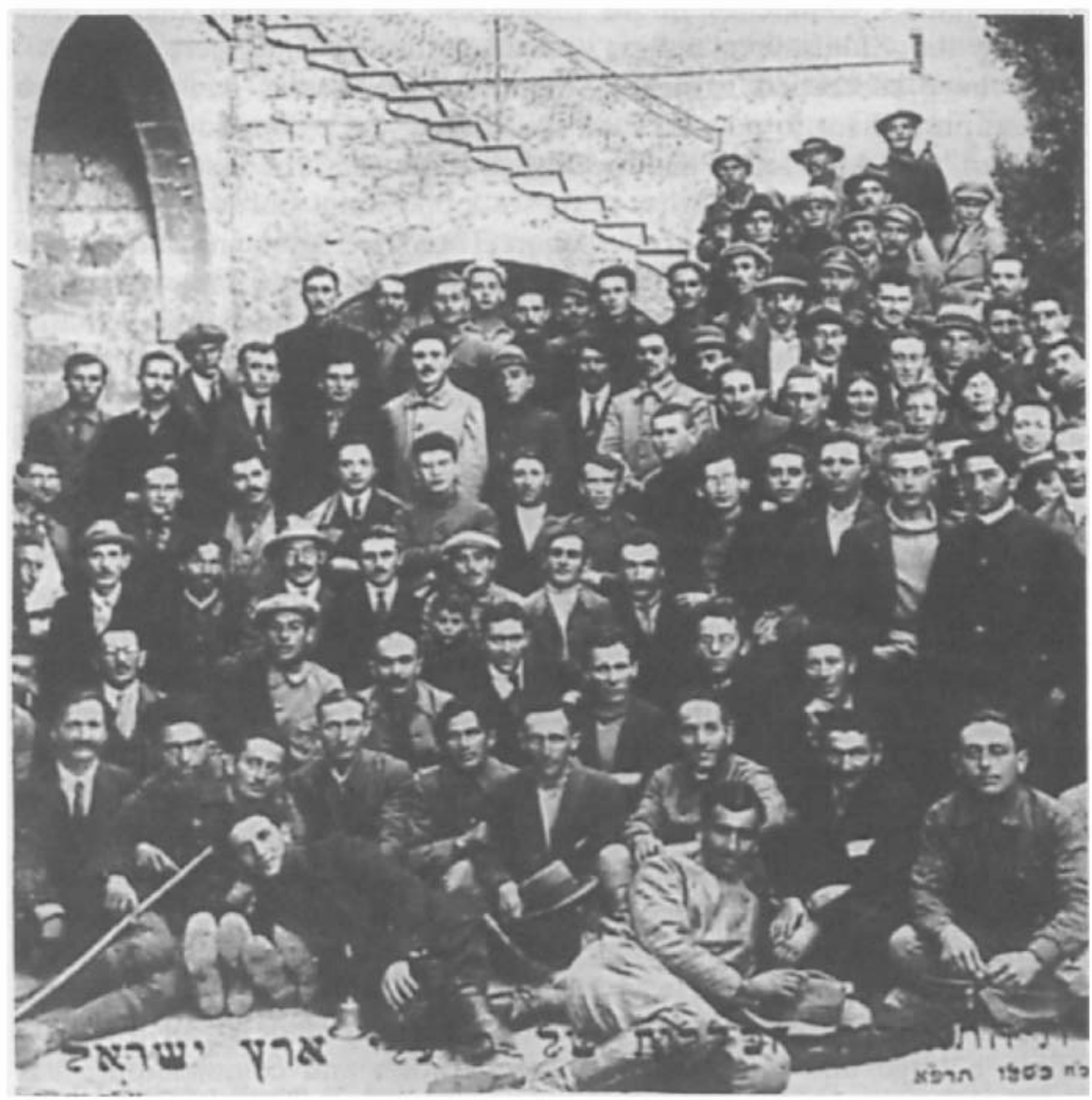

Figure 1. The founding conference of the Histadrut. Haifa. 1421 (Reprinted from $Y$. Lossin. Pillar of Fire (Shikmona Publishing Company Lid. Jerusalem. 1983). p. 132)

necessary to defend their jobs and the conditions that they had attained. against competition from cheaper Arab labour. ${ }^{22}$ Vandervelde also remarked that although Poale Zion shared the long-term Zionist objective of attaining a majority in Palestine, its actions, as those of the Histadrut. indicated "that it is a stylistic formulation or, more or less. a pious hope". ${ }^{43}$ He considered, therefore. that in the long term there were no insurmountable obstacles to good relations between Palestine's Arab and Jewish communities.

The communal clashes that broke out in Palestine. in August 1929. leaving over 200 dead and several hundred injured. did not shake

"Vandervelde, Le pays alsrael. p. 72: Wedgwood. The Seventh Dominion, p. 86.

$\therefore$ Vandervelde. Le pays disrael. p. 126. 
Vandervelde's confidence in his prognosis. He attributed their cause, echoing the Zionist explanation, to the "effendis and their fanatics": "they have succeeded to arouse the fanatized masses and have been able to push them to massacre, to spill blood and to destroy property". Between "the Arab fellah and the Jewish chalutzim", he asserted, "there is not in the large majority of cases opposition but community of interest". Blum, Filipo Turati, Albert Thomas, Huysmans and several other labour figures joined the condemnation of Arab violence; they, too, attributed its cause to the effendis and religious leaders manipulating the Arab masses. "But the fellahs, the peasants", declared Blum, "those who have really benefited from this Jewish colonization and whose standard of life was always rising, in part, under the influence of the workers' movement, have no interest to struggle against Jewish colonization."4s The riots in Palestine, however, led to pressure from within the British colonial service for steps to be taken to mitigate Arab hostility to Zionist settlement and the Labour government, under Ramsay MacDonald, responded, in 1930, with the publication of a policy statement formulated by the Colonial Secretary, Lord Passfield (formerly Sidney Webb). The Passfield White Paper's proposal to restrict Jewish immigration and land purchase in Palestine provoked vigorous opposition from Zionist organizations around the world and was withdrawn by MacDonald mainly out of concern for its impact in the United States. The White Paper also drew condemnation from the Socialist Committee for Workers' Palestine. It passed a resolution calling on the MacDonald government to honour the Labour party's past commitment to the Zionist project and argued that it was incumbent on the British government, as the mandatory power, "to encourage actively and by all available means a large and intense Jewish immigration and colonization". ${ }^{46}$ It was a measure of the extent to which most leading social democrats had moved away from the end-of-war commitment to the right of colonial peoples to self-determination that the Committee expressed no sympathy for Passfield's attempt to mount a defence of Arab interests on the basis of "native paramountcy". In the debates surrounding the 1929 riots and the Passfield White Paper, the social democratic position on the Arab-Jewish conflict crystallized behind a rigid, class reductionist diagnosis.

In 1933, the Histadrut launched a campaign to forcibly evict Arab workers from Jewish construction sites and enterprises in the cities, ${ }^{47}$ yet the following year a statement in the name of the Socialist Committee for Workers' Palestine and signed, among others, by Vandervelde, Blum

" Comité Socialiste, Bulletin no. 4, November 1929.

is Ibid.

4omité Socialiste, Bulletin no. 6, February 1931.

7 S. Flapan, Zionism and the Palestinians (London, 1979), p. 206. 
and Gillies (the British Labour party's Secretary), stated: "It is demonstrated in practice that the progress of Jewish colonization benefits the Arab labourers themselves, and that already now the obstinately pursued efforts of the Jewish Labour party of Palestine and the General Federation of Labour is leading to more and more splendid results." 48

The view that Zionism was furthering unity among the mass of Jews and Arabs on a class basis continued to be maintained during the 19361939 Arab rebellion. Tom Williams, speaking for the Labour Party in a House of Commons debate on Palestine, insisted that, "broadly speaking the workers' interests are identical whether they are Jews or Arabs" and added: "We do not think that a comparatively few either feudal landlords or modern capitalists should stand in the way." European socialist leaders generally failed to take cognizance of Labour Zionism's divisive practices. An indication of the range of these practices and that, despite the silence from the leadership, they met some criticism from socialist activists has been provided by a director and founding member of Solel Boneh, the Histadrut's largest commercial enterprise. David Hacohen, reminiscing about his student days in London after World War I, recalled:

When I joined the socialist students - English, Irish, Jewish, Chinese, Indian, African - we found that we were all under English domination or rule. And even here, in these intimate surroundings, I had to fight my friends on the issue of Jewish socialism, to defend the fact that I would not accept Arabs in my trade union, the Histadrut; to defend preaching to housewives that they not buy at Arab stores; to defend the fact that we stood guard at orchards to prevent Arab workers from getting jobs there [. . . T To pour kerosene on Arab tomatoes; to attack Jewish housewives in the markets and smash the Arab eggs they had bought; to praise to the skies the Kereen Kayemet [Jewish Fund] that sent Hankin to Beirut to buy land from the absentee effendi [landlords] and to throw the fellahin [peasants] off the land $\left[\ldots . . .^{30}\right.$

The vitality of Arab nationalism also appears to have been more readily recognized outside the ranks of social democratic leaders. It was applauded by the communist movement and acknowledged by successive Royal Commissions, appointed to inquire into the conflict in Palestine.

The Haycroft Commission, which investigated the 1921 disturbances, dismissed the argument that they had been engineered by Arab leaders.

4 Comité Socialiste, Bulletin no. 8, February 1934; Ramsay MacDonald, when retracting the Passfield White Paper, accepted the Zionist aim to exclude Arab labour from the Jewish sector: "The principle of preferential and, indeed, exclusive employment of Jewish labour by Jewish organizations, is a principle which the Jewish agency are entitled to affirm." Hansard, Commons, 13 February 1931, vol. 248, col. 757.

49 Hansard, Commons, vol. 326, cols 2337, 2344, 21 July 1937; also see P. Kelemen, "Zionism and the British Labour Party: 1917-1939". Social History, 21, 1 (January 1996), pp. 71-87.

${ }^{30}$ Quoted in A. Bober (ed.), The Other Israel (New York, 1972), p. 12. 


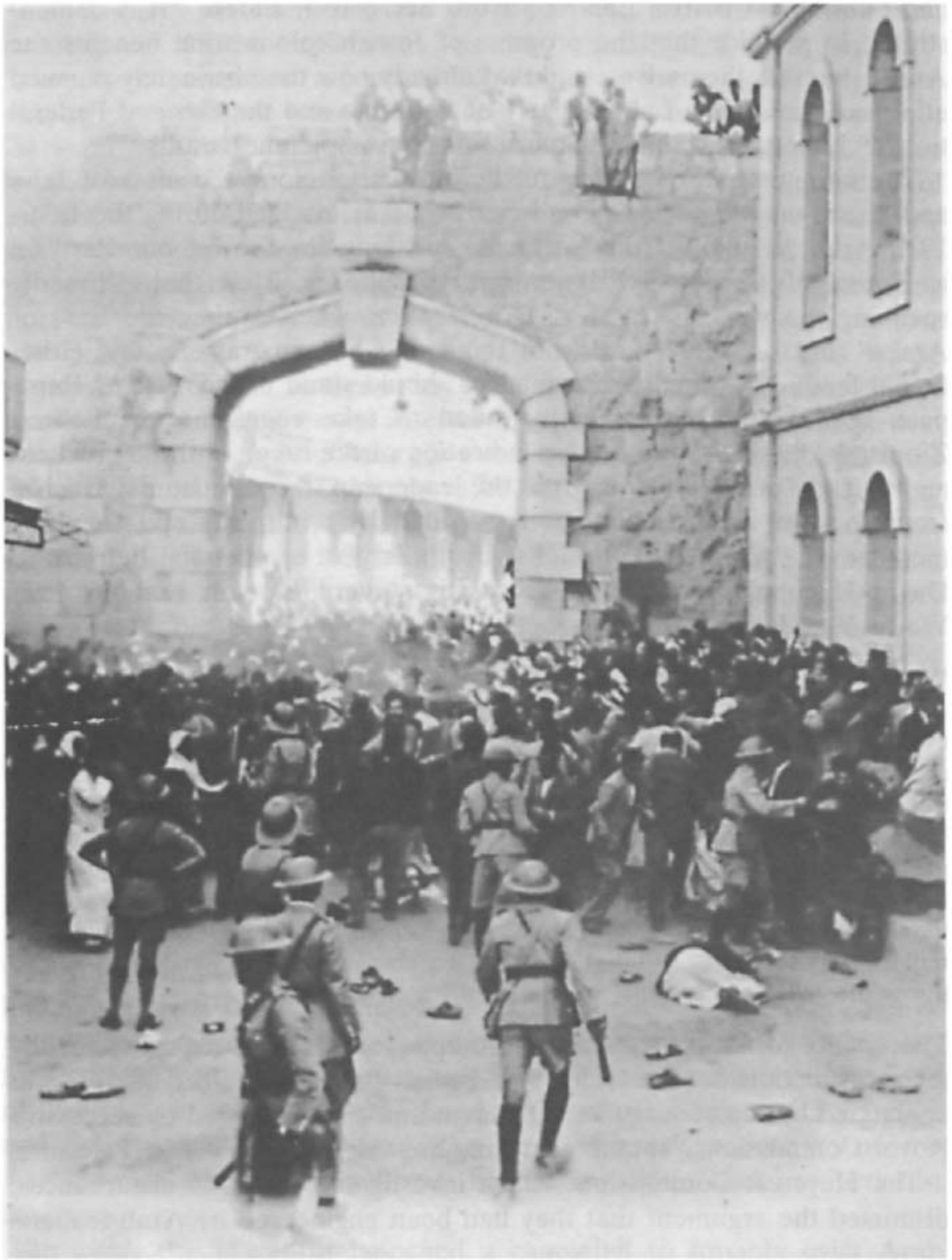

Figure 2. The aftermath of a Palestinian demonstration protesting against Zionist immigration. New Gate. Jerusalem. 1933 (Reprinted from W'. Khalidi. Before Their Diaspora (Institute for Palestine Studies. Washington. DC. 1984), p. 108, picture 107) 
It concluded that "the general belief that the aims of the Zionists and Jewish immigration are a danger to the national and material interests of Arabs in Palestine is well nigh universal amongst the Arabs, and is not confined to any particular class [...]. ${ }^{51}$ The Shaw Commission with the exception of its Labour party member Harry Snell - likewise rejected the interpretation of the 1929 disturbances that attributed its cause to incitement by Arab leaders. The Arab people of Palestine, the majority report stated, "are united in demanding some measure of self-government". ${ }^{2}$ An even more emphatic recognition of Arab nationalism in Palestine came from the Peel Commission which, in 1937, recommended the partition of the country.

Among social democrats, Julius Braunthal, who had been editor of the Austrian socialist party's newspaper and after World War II became the LSI's secretary, was one of the few prepared to acknowledge the deep roots of Arab nationalism in Palestine. He, too, saw the effendis as the main force behind Arab nationalism but observed, in 1935: "Jewish workers against Arab workers: the national conflict cuts right to the bottom of the social system, touches the Arab nationalist movement even in the Arab proletariat.",53

The social democratic characterization of Arab hostility to Zionism as the expressions of narrow, feudal and religious interests functioned in opposition to the universalism it attributed to Jewish nationalism and served to validate the alleged superiority of the Jewish over the Arab claim to Palestine. Yet the identification of the Zionist pioneer in Palestine with European civilization and socialism, developed not only in conjunction with Orientalist notions about the Arabs, it also drew on anti-Semitic prejudices.

The LSI and individual socialist parties repeatedly condemned antiSemitism in Eastern Europe and called for the civil rights of Jewish minorities to be respected. It was a position that had become axiomatic to socialists but one that concealed an ambivalent attitude towards Jews. The ambivalence was manifested in the pro-Zionism of some of the leading European socialists: the Zionist pioneer, who was taking trade unionism and economic development into the Orient, was at the same time credited with transforming the Jew into a true proletarian. The

\footnotetext{
${ }^{51}$ Report of the Commission of Inquiry on Disturbances in May 1921, Cmd. 1540 (London, 1921), p. 45.

s2 Report of the Commission on the Palestine Disturbance of August 1929, Cmd. 3538 (London, 1930), pp. 129-130.

${ }^{53}$ Braunthal, "Arabs and Jews in Palestine", p. 474; a few Labour Zionist leaders also recognized, in private, the reality of Arab nationalist opposition to Zionism. Moshe Shertok, who was to become Israel's first foreign minister, wrote to Ben-Gurion in 1921: "For the sake of self-delusion we have made it all sound easy and simple - a handful of effendis against the masses of workers." Quoted in Y. Gorny, Zionism and the Arabs, 1882-1948 (Oxford, 1987), p. 135.
} 
virtues that social democracy saw in the Jewish labour movement in Palestine, tended to be the mirror inversion of anti-Semitic stereotypes. The Jews' perceived otherness, an attribute of their marginality, was the quality that made them into the ideal purveyors of a positive colonial policy in the Orient. For Vandervelde, Jews could form the bridge between Europe and Asia because they have "European ideas" but belong to the "Asian race". ${ }^{54}$ Huysmans elaborated on this point in response to Kautsky. The latter had disputed the Zionist claim that Jews had a special connection with Palestine. It was a country under Muslim influence, argued Kautsky, while the Jews belonged to European civilization. "Is that certain?" asked Huysmans and referring to Victor Adler's dubious witticism: "Dear comrade, we should have Jews but not too many", Huysmans remarked: "Not too many' was intended to say that the absorption capacity of Western people is limited, as a consequence of the lack of ability to adapt on the part of many Jews." ss Thus fear and racialization of the Jew were also at work in some of the pro-Zionist arguments of social democracy, a fact that was to have an impact on the latter's perception of Zionism in the context of the Nazi persecution of Jews.

From the early 1930s, the advance of fascism and the arrival, in the liberal democracies, of Jews seeking refuge from Nazism dominated the political environment in which socialist discussion of Zionism unfolded. The social democratic parties, following resolutions passed at the 1933 Vienna Congress of the LSI, launched campaigns to boycott politically and economically Nazi Germany, to mobilize support for the refugees from fascism and to press for disarmament and observance of the Covenant of the League of Nations. In terms of relations between the Zionist movement and social democracy, the boycott was a source of tension, while on the refugee issue the political interests of the two movements converged.

A boycott of German goods came to be advocated in a number of countries following Hitler's electoral triumph in the election of March 1933. It gained backing mainly from Jewish groups, trade unions and socialists. The strongest encouragement for such a campaign came from the US, Britain and Holland and it had a formal launch at an international conference initiated by Lord Melchett, the head of Imperial Chemical Industries. ${ }^{56}$ The LSI and the International Federation of Trade Unions - which worked in close liaison throughout the 1930 s - called for working-class organizations to endorse the boycott. The LSI Executive approved the campaign as a demonstration of anti-fascism but some of

st Comité Socialiste, Bulletin no. 11, January 1938.

is La Vie Socialiste, December 1929.

s6 J.-P. Schreiber, "L'attitude des Juifs en Belgique face au Nazisme: le boycottage Economique, 1933-1939", in R. Van Doorslaer et al., Les Juifs en Belgique (Brussels, 1994), p. 80 . 
its members were sceptical about its likely effectiveness. Blum felt that it might be counter-productive and serve to strengthen the regime, "by building around it collective suffering and collective resentment". ${ }^{57}$ The campaign nevertheless initially alarmed the Nazi government since it was anxious to relaunch the economy by expanding exports. It came to see a way of undermining the boycott by what became known as the transfer agreement or Haavara.

This agreement, made between the Nazis and the Zionist leadership in Palestine and Germany, was based on German Jews selling their property to the Nazi government from which they were to be compensated, on emigrating to Palestine, by receiving part of their wealth in the form of local currency and goods imported from Germany. In addition, importers in Palestine of German goods were to make some payment in Palestinian pounds, "so that Germany would earn some foreign currency", with the remainder being "paid in Reichsmark from the blocked Jewish assets". ${ }^{58}$ From the Nazi point of view, the transfer agreement helped Germany to be rid of its Jews, to increase its exports and to weaken the anti-boycott campaign. For the Zionists, it was a way of bringing economic assets into Palestine and of exceeding the numbers permitted entry by the British, under its annual quota, because those with capital were not subject to restriction. The agreement provoked controversy within Jewish communities though the dispute tended to be along the split between Zionists, for whom emigration to Palestine was the priority, and anti-Zionists, who believed that the Jewish presence in Germany should be defended and that the priority was the defeat of fascism.

The transfer agreement presented an awkward problem to campaigners for the boycott. The boycott had been breached from several countries by companies pursuing their commercial interests but its violation by Jewish Palestine was perceived by some advocates of the boycott as particularly damaging. When the boycott was contravened in Scandinavia or South America, commented Friedrich Adler, the LSI's Secretary, this had "considerable lesser consequences so far as the general boycott propaganda is concerned, than when the opponents of this are in a position to say that 'the Jews themselves' and 'Palestine itself' are in agreement with the infraction of the boycott". Yet Adler conceded that at least the people uprooted in this way did not have the added misfortune of "being robbed of their means as well". 59 He also accepted that maintaining the boycott called for a sacrifice primarily from Jews because it would close an escape route for them. But the escape route that it provided - and this added to the discomfiture of socialists - had "a

7 Le Populaire, 23 May 1933.

ss F.R. Nicosia, The Third Reich and the Palestine Question (London, 1986), p. 47.

59 Adler to Jarblum, 4 May 1936, SAI 2523/85-87. 
distinct bias towards the capitalist classes", noted an internal memorandum by the British Labour party's International Department. ${ }^{60}$ Adler, too, remarked that the transfer enabled "a small upper strata" from being robbed of its property but "the vast mass of Jews, with whom we as Socialists are primarily concerned, cannot be robbed of any property because they never had any". ${ }^{61}$ Poale Zion pressed the LSI Secretary not to draw attention to the Zionist contravention of the boycott and the LSI, like the Labour party, did not pursue the matter. The agreement does not appear to have affected the attitude of social democratic leaders to Zionism, not least because it was rapidly overshadowed by the refugee crisis.

Significantly, the International Department's memorandum in evaluating the transfer agreement had identified as one of its positive aspects that wealthy Jewish refugees would not require assistance and may be able to provide financial help to the poorer emigrants. It would thereby ease, it argued, the "very difficult problems confronting organizations which are trying to deal with German refugees". ${ }^{62}$ The task of coping with the economic and political consequences of large numbers of Jewish refugees, arriving from the beginning of 1933 in the European countries outside fascist control, became a central preoccupation of the social democratic parties in those countries and constituted a powerful influence on their attitude to Zionism.

From the beginning of 1933 until the spring of 1938, around 150,000 people, mainly Jews, fled from Germany. In July 1938, an International Conference attended by thirty-two countries and by organizations dealing with refugees, met in Evian to discuss the growing refugee problem. Most of the governments avoided committing themselves to an increase in the numbers of refugees that they were prepared to take and some wanted tighter restrictions. ${ }^{63}$ In the following twelve months the scale of the problem dramatically escalated. In August 1939 an LSI bulletin reported: "Since Evian, the problem of the refugees has become vaster and more complicated. In addition to some 500,000 Jews in Germany and Austria, nearly 300,000 Jews of Czechoslovakia are in search of a new home. Five thousand Jews have had to leave Memel overnight. Ten thousand have had to leave Italy." "t

In response to the growing number clamouring for entry permits from the liberal democracies, socialist leaders in the 1930s appealed to their governments for the relaxation of immigration and asylum rules. In 1938, the LSI Executive called on the Evian conference to ensure that

\footnotetext{
60 "Jewish Emigration from Germany and German Exports", Intemational Department, Labour Party, SAI 2523/9.

61 Adler to Jarblum, 4 May 1936, SAI 2523/85-87.

62 Adler to Jarblum, SAI 2523/12.

${ }^{63}$ Nicosia, The Third Reich and the Palestine Question, p. 157.

64 Communications on the Conditions of Political Prisoners, 18 August 1939.
} 
the granting of visas was not limited "to refugees possessing a fortune or an income". ${ }^{65}$ The LSI, through its Commission of Enquiry into the Conditions of Political Prisoners, sought to draw attention to the "political refugees", which included socialists and trade unionists but, for the most part, carried out propaganda and fund-raising as part of a general campaign against fascism. Individual socialist parties carried out similar work in their own countries. In France, the Socialist party imposed an annual one-franc levy on each member for its "Solidarity Fund for the Victims of Fascism"; in Britain, the Labour party and the Trades Union Congress, under the National Council of Labour, raised funds for refugees and their dependants. ${ }^{66}$ Alongside the widely felt sympathy among socialists for those fleeing from fascism and calls by some socialist leaders for their governments to liberalize entry conditions, the refugee presence also provoked alarm and hostility in the labour movement.

The first wave of refugees from Nazism arrived in countries still deep in recession. France, the largest recipient of German refugees, had 12.6 per cent of the working population unemployed in 1935 and 50 per cent of the workers had reduced hours of work. In Britain, unemployment peaked in 1932 but hovered between 9 and 12 per cent until the outbreak of war. Belgium, Switzerland and the Netherlands also experienced severe depression. ${ }^{67}$ The arrival of Jewish refugees in these conditions was exploited by the far right to gain influence through xenophobic and anti-Semitic agitation. The Confédération Générale du Travail (CGT) supported some demonstrations which marched to the slogan "France for the French" and the TUC Congress, in 1938, called for a limit to the number of refugees allowed into the country in any one year. ${ }^{68}$ The scale of anti-refugee sentiment and the prospect of fascist groups gaining support on that basis among workers spread alarm among socialists. It was reflected in their response to the refugees.

No socialist party was prepared to advocate the acceptance of unrestricted numbers of refugees. Albarda, leader of the Social Democratic party in the Dutch Parliament, remarked: "It cannot be disputed that a Government which accorded the right of asylum on the most generous scale might create serious difficulties for its own country"; and Lansbury, as leader of the Labour party, rejected the suggestion from one of his

S3 Ibid, 6 July 1938.

* International Information, 17 November 1938; Circular no. 35, 6 December 1935, Labour Party Archives, WG/REF/6 (Manchester Labour History Museum).

${ }^{67} \mathrm{G}$. Noiriel, Workers in French Society in the 19th and 20th Centuries (Oxford, 1990), p. 162; S. Pollard, The Development of the British Economy (London, 1983), p. 155; A. Maddison, "Economic Policy and Performance in Europe, 1913-1970", in C.M. Cipolla (ed.), The Fontana Economic History of Europe. The Twentieth Century (Glasgow, 1976), p. 465.

is R. Schor, L'opinion française et les étrangères en France, 1919-1939 (Nancy, 1985), p. 564: Report of the Proceedings at the 70th Annual Trade Union Congress (London, 1938), p. 208. 
own MPs that Britain should allow the mass entry of Jewish refugees. ${ }^{69}$ In 1934, a resolution by the Socialist Committee for Workers' Palestine, signed among others by Vandervelde, Blum and Gillies, pointed to Palestine as the solution. Immigration controls in the US, anti-Semitism and overcrowding in Eastern Europe, and the economic conditions in Western Europe, imposed strict limits, it said, on work and asylum opportunities for Jews fleeing their country of origin. In these conditions, "Palestine offers Jewish immigration possibilities which are increasing in the same proportions as the difficulties elsewhere". ${ }^{\text {to }}$ There were also calls from socialists for an "international solution" to the refugee crisis and for the British Empire to provide refuge, but the supporters of Zionism now presented Palestine as the most realistic solution. The British Labour party leadership opposed the restrictions on Jewish emigration to Palestine that the government had introduced, in 1937, in response to the Arab rebellion. Although the rebellion was not defeated for a further two years, the situation in Europe proved to be a more pressing consideration for socialist politicians. It was yet a further reason to ignore the force of Arab nationalism and to maintain that the interests of the Arab masses were compatible with Zionism. By the 1930s, the pro-Zionism of the social democratic movement was sustained not merely by its leaders' imperial vision of extending socialism to the Orient but also by their sense of weakness in the face of fascism. They wanted to see some of the Jewish refugees diverted to Palestine, believing that efforts at their mass resettlement in Europe would strengthen the popular appeal of anti-Semitism and enable the extreme right to capture its working-class electoral base.

The concerns which fuelled socialist pro-Zionism in the inter-war years do not readily conform to a history of heroic anti-fascism or of consistent anti-colonialism, to which the socialist movement lays claim. The post1945 political climate in Europe did not bring about a reappraisal: support for a Jewish state was widely seen as a necessary recompense to the Jews who survived Nazi extermination. But support for the state of Israel could not be dissociated from taking position on the future of the Palestinians or on the wider Arab-Israeli conflict and, over these issues, the social democratic outlook continued to reproduce the blind spots that had characterized its earlier endorsements of Zionism.

6ommunications on the Conditions of Political Prisoners, 18 October 1933; Hansard, -Commons, vol. 304, col. 2101, 25 July 1935.

to Comite Socialiste, Bulletin no. 8, February 1934. 